\title{
IZOBRAŽEVANJE STAREJŠIH ZA PROSTOVOLJNO DELO V MUZEJIH IN SPREMINJAJOČA SE VLOGA MUZEJA V (STARAJOČI SE) DRUŽBI
}

\section{POVZETEK}

Semantično polje tega prispevka zajema koncepte, kot so izobraževalna vloga muzejev, organizirano prostovoljstvo, kulturna dediščina. Avtorica se v prispevku sprašuje o vlogi muzeja $v$ starajoči se družbi in preuči sodobni model izobraževanja starejših odraslih v muzejih, ki naj na konceptualni ravni povezuje izkustveno znanje starejših z nesnovno obliko kulturne dediščine in prostovoljstvom. Avtorica nadalje predstavi razvojni model Mediator v kulturi, ki so ga zasnovali na Slovenski univerzi za tretje življenjsko obdobje, pri tem pa so v partnerstvo povabili nekatere slovenske muzeje. Ta model ima namen spodbuditi in razviti prostovoljno delo starejših odraslih v muzejih, narediti izobraževanje starejših družbeno vidno in koristno, saj naj se to zaokroži v delo prostovoljnih kulturnih mediatorjev v muzejih. Po tem modelu se starejši izobražujejo tematsko in namensko za prostovoljno delo v muzeju, muzejski delavci pa za razumevanje narave in vrednot prostovoljstva, za pripravljenost na spremembo in ustvarjanje novih muzejskih prostovoljskih vlog za starejše. Ker je družbena skupina starejših odraslih (krivično) odrinjena na družbeni rob in prostovoljstva v našem okolju ne cenimo dovolj, je v model zajeta sistematična javna kampanja. Avtorica analizira tudi vrednost in namen povezav med muzejem in nevladnimi organizacijami $v$ luči družbenega poslanstva muzejev in spreminjajoče se vloge javnih kulturnih ustanov.

Ključne besede: izobraževalna vloga muzeja, mediator v kulturi, starejši prostovoljci, kulturna dediščina

\section{$\breve{\ddots}$}

lanek je plod analize literature in študij s področja geragogike, muzeologije in sociologije ter je interpretacija izsledkov participativnega raziskovanja na področju izobraževanja starejših za prostovoljno delo v muzejih, ki ga je vodila Slovenska univerza za tretje življenjsko obdobje. Temelji na opazovanju in preučevanju inducirane prakse prostovoljstva starejših (mediatorjev v kulturi) v osmih slovenskih muzejih med letoma 2006 in 2009 ter izsledkih, pridobljenih pri razvoju izobraževalnega modela Mediator v kulturi (izobraževanje starejših odraslih za prostovoljno delo v muzejih, izobraževanje muzejskih delavcev za razumevanje dejavne starosti in ustvarjanje novih prostovoljskih vlog za starejše, vzpostavljanje strukturnih in organizacijskih sprememb v muzejih, prepričevanje javnosti). Razvoj
Rajka Bračun Sova, Samostojna pedagoginja $\checkmark$ kulturi in kustosinja Slovenska univerza za tretje življenjsko obdobje 
modela smo pospremili z raziskovanjem pa tudi s sprotnim in končnim posploševanjem spoznanj; dobre prakse smo vtkali v nadaljnji razvoj modela, slabe smo opustili.

Preliminarne raziskave so potekale na manjšem vzorcu $\mathrm{v}$ obliki začetnih razgovorov $\mathrm{s}$ slušatelji univerze o njihovih Muzeji so vir zna-
nja in sredstvo
vzgoje. izkušnjah s prostovoljnim delom in motivih za vključitev v prostovoljno delo na področju kulturne dediščine. Spremljali smo tudi odzive muzejskih delavcev na spreminjajoče se delovno okolje. V eni od raziskav, ki so spremljale posamične vidike razvoja modela, smo analizirali stališča do prostovoljstva, do starosti in do starejših v vlogi prostovoljcev.

$\mathrm{V}$ obdobju intenzivnega razvoja modela smo preučevali tujo prakso prostovoljnega dela $\mathrm{V}$ muzejih. Nekatere muzeje, ki imajo razvito prakso prostovoljstva, smo obiskali (Britanski muzej, Muzej John Soane

Glavni cilj muzeja ni le hramba umetnin, ampak dia$\log$ z obiskovalci. v Londonu, Muzej Belvedere na Dunaju), od muzejskih delavcev, odgovornih za prostovoljstvo na različnih področjih dediščine, smo informacije pridobivali tudi $\mathrm{v}$ pisni obliki (Organizacija National Trust, Vojni muzej v Duxfordu, Narodna galerija portretov v Londonu). Model smo javno predstavljali v lokalnih, nacionalnih in evropskih okoljih, izsledke pa integrirali vanj, če se je to izkazalo kot ustrezno.

\section{UVOD}

Uvodoma velja osvetliti znano dejstvo, da se med vzgojno-izobraževalne ustanove uvrščajo tudi muzeji. Morda pa je manj znano to, da so muzeji ustanove, ki imajo predvsem vzgojnoizobraževalno poslanstvo. Kulturna in naravna dediščina, ki jo muzeji hranijo, je dostopna javnosti in naloga muzejev je, da jo »interpretirajo $\ll$ in »popularizirajo $($ ICOM $)$.
$\mathrm{V}$ preteklosti to ni bilo tako, saj so zbirke umetniških, zgodovinskih in naravoslovnih predmetov nastajale pod taktirko družbenih elit in so bile dostopne samo izobraženim in vplivnim posameznikom. Javna kulturna vloga muzejev se je konceptualizirala šele po francoski revoluciji. Takrat muzejska zbirka postane »vir znanja in sredstvo vzgoje « (Tavčar, 2003). Vzpostavljena izobraževalna vloga muzeja je dolgo živela $v$ senci drugih muzejskih ved. $\mathrm{V}$ drugi polovici prejšnjega stoletja pa pride $\mathrm{v}$ razmerju med muzejem in obiskovalci do »kopernikanskega preobrata« (Tavčar, 2009: 111). Izobraževanje, poprej obrobna muzejska dejavnost, postane ena središčnih funkcij muzeja. Zbiranje in hranjenje predmetov za muzeje tako nista več končni cilj, temveč predvsem sredstvo za dosego njihovega prvega cilja, dialoga $z$ obiskovalci. Izobraževanje $\mathrm{v}$ muzejih se je tedaj začelo teoretsko, metodično, organizacijsko in še kako drugače spreminjati. Muzeji začnejo raziskovati strukture in značilnosti dejanskega in potencialnega muzejskega občinstva, pomembno postaja skupnostno učenje.

Leta 2006 je bil na Slovenski univerzi za tretje življenjsko obdobje $\mathrm{v}$ sodelovanju $\mathrm{z}$ Narodnim muzejem Slovenije zasnovan nov izobraževalni program za starejše, ki smo ga poimenovali Mediator v kulturi. Starejše odrasle izobražujemo za prostovoljno delo $\mathrm{v}$ kulturni dediščini - za varovanje kulture, njenih snovnih in nesnovnih oblik. Izobražujemo tudi muzejske delavce za razumevanje dejavne starosti in ustvarjanje novih muzejskih prostovoljskih vlog za starejše. Program se osredotoča na oblikovanje dinamične (družbene) vloge muzejev, kjer sta kultura in prostovoljstvo razumljena kot družbeni sestavini, ki imata kohezivno moč. Program se oplaja z vsemi predhodnimi izkušnjami in teorijo Slovenske univerze za tretje življenjsko obdobje (Findeisen, 2009).

Sodelovanje med univerzo za tretje življenjsko obdobje in muzeji ima dolgo tradicijo in 
morda velja poudariti, da se je ta odnos gradil tako, da se je sprva predvsem univerza povezovala $\mathrm{z}$ muzeji in ne muzeji $\mathrm{z}$ univerzo. Od ustanovitve univerze leta 1984 dalje so se povezave $\mathrm{z}$ muzeji tkale skorajda organsko prek temeljnih izobraževalnih programov najrazličnejših humanističnih in družboslovnih vsebin ter programov izobraževalnega in kulturnega turizma. Programi temeljijo na sinergiji »učilnice« in »terena«, zato bi lahko dejali, da je učenje $\mathrm{v}$ avtentičnih kulturnih in naravnih okoljih »del kurikuluma«. Da so študijske skupine univerze že od nekdaj pogosti obiskovalci muzejev, ilustrira podatek iz leta 1993, ko je ljubljanska Univerza za tretje življenjsko obdobje v enem letu kar 20-krat obiskala Narodno galerijo in po pogostnosti obiska prehitela vse izobraževalne ustanove takrat (Tavčar, 1997: 68). Tovrstni obiski študijskih skupin v muzejih so takrat temeljili in še danes temeljijo na organiziranih ogledih razstav in predavanjih, ki jih izvajajo muzejski kustosi in v muzeju gostujoči predavatelji. Izobraževalni programi, ki bi temeljili na ideji o dejavnih starejših študentih, torej starejših, ki v muzeju znanje ne samo pridobivajo, ampak ga tudi prispevajo, pa so v slovenskih muzejih redkost. $\mathrm{K}$ zapolnjevanju te vrzeli smo želeli prispevati z novim izobraževalnim programom za starejše.

Ali je mogoče muzejski izobraževalni program za starejše preprosto nasloniti na cilje in metode izobraževanja starejših na univerzi za tretje življenjsko obdobje? Trdimo, da ne. Če bi program izoblikovali zgolj v skladu z izobraževalnimi cilji in metodami univerze, $s$ tem ustaljenih izobraževalnih praks za starejše v muzejih najverjetneje ne bi bistveno presegli. Da pa bi dosegli presežek in izoblikovali program, ki ga je mogoče organsko integrirati v muzeje, smo morali preučiti tudi in predvsem cilje in metode izobraževanja v muzejih. Naše predvidevanje, da so izobraževalni cilji univerze za tretje življenjsko obdobje in muzejev lahko komplementarni, se je potrdilo.

\section{IZOBRAŽEVALNA VLOGA MODERNEGA MUZEJA: TRANSMISIJSKI PEDAGOŠKI IN ANDRAGOŠKI MODEL}

Izobraževalna vloga muzeja $v$ današnjem pomenu besede se vzpostavi s procesom demokratizacije muzejskih zbirk na prelomu iz 18. v 19. stoletje. Takrat se začnejo zasebne aristokratske zbirke odpirati javnosti, ustanavljajo se javni in tudi prvi nacionalni muzeji. Skozi desetletja in stoletja nakopičeno muzejsko gradivo zdaj postane javna dobrina, »vir znanja in sredstvo vzgoje « (Tavčar, 2003: 143). Muzej postane prostor organiziranega izobraževanja širših ljudskih množic. To se sprva kaže predvsem skozi izbor in razporeditev muzejskih eksponatov po prostoru, vsebinska pojasnila, odpiralni čas, omejeno število obiskovalcev in druga »hišna pravila«. Od teh prvih korakov na poti demokratizacije muzeja pa do časa, ko v muzejih začnejo razmišljati o skupnih značilnostih posameznih muzejskih ciljnih skupin, denimo starejših odraslih, o njihovih potrebah in zanimanjih in o tem, kako se jim približati, pa je pot še dolga.

Značilnost modernega muzeja kot družbenega prostora, ki se v 19. in v prvi polovici 20. stoletja razvija vzporedno z nastankom javne šole in $\mathrm{z}$ izobraževanjem, je, da svoje obiskovalce obravnava kot monolitno občinstvo, »splošno publiko«, »ki v muzeju išče nekaj, česar nima, ki je potrebna vzgoje in izobrazbe in od katere se pričakuje, da se v muzeju obnaša kot prejemnik znanja (Hooper-Greenhill, 2000: 125). Neveden in neprizadet obiskovalec, pasivni prejemnik informacij, je tako le »prazna posoda, ki se v muzeju napolni« (idem). Napolni se z gotovim, izoblikovanim znanjem, ki je, povezano z znanstvenimi disciplinami (umetnostno zgodovino, arheologijo, zgodovino idr.), konstrukt kustosovega poznavanja muzejskih zbirk. Premočrten komunikacijski model od muzeja oziroma kustosa k obiskovalcu HooperGreenhillova imenuje transmisijski pedagoški 
model. Temelji na teoriji in praksi objektivizacije muzejskih predmetov, racionalizacije in vizualizacije sveta, nadzorovanem doživljanju snovnega, enosmerni, »proizvodni« komunikaciji. Pedagogika modernega muzeja temelji na popreproščeni ideji, da muzejski predmet, če je ustrezno postavljen na ogled, govori kar sam zase (Hooper-Greenhill, 2000: 126-131).

\section{IZOBRAŽEVALNA VLOGA POST(MODERNEGA) MUZEJA: TRANSFORMATIVNI PEDAGOŠKI IN ANDRAGOŠKI MODEL}

$\mathrm{S}$ prehodom iz industrijske $\mathrm{v}$ informacijsko dobo, z oblikovanjem storilnostne, na znanju temelječe, a tudi močno individualizirane družbe, dobimo novo komunikacijsko paradigmo. Komunikacija ni več samo transmisija, preprost in hiter prenos sporočil, ampak postane kulturna praksa in vrednota, sestavina

\section{Znanje ni enoznač- no; sooblikujejo ga kustos in obisko- valci $v$ muzeju!}

kompleksnega socio-kulturnega procesa. Novo spoznanje, da je muzejski predmet mogoče interpretirati $z$ dveh vidikov, muzejskega (kustosovega) in obiskovalčevega, muzej preobrazi v prostor kulturnotransformativnega učenja.

Transformativni pedagoški in andragoški model temelji na novih socioloških, psiholoških, pedagoških, andragoških, geragoških in filozofskih teorijah, ki znanje in vedenje opredeljujejo hkrati kot izhodišče in nasledek najrazličnejših interpretacij (Hooper-Greenhill, 1994).
Glas posameznika zrcali tudi družbene in kulturne značilnosti njegove socialne mreže, saj je vsaka osebna življenjska zgodba tudi zgodba neke skupnosti, na primer generacijske. Starejši odrasli, ki so predmet naše obravnave, so bili na svoji življenjski poti pod vplivom individualnih in kolektivnih dogodkov, pod vplivom družbenih, gospodarskih, političnih in drugih pričakovanih ali nepričakovanih dogodkov. Oblikovalo pa jih je, razumljivo, predvsem njihovo doživljanje teh vplivov. Ob tem se je z njimi oblikovala tudi skupnost. Razmislek o muzejskem občinstvu tako ni preprosta stvar, je pomembno dejanje, ki naj oblikuje politiko in prakso posameznega muzeja.

$\mathrm{V}$ novem pedagoškem in andragoškem modelu muzejski kustos, poprej nezmotljiva avtoriteta, ob upoštevanju kritične pedagogike nastopa kot mediator. To pomeni, navaja Chambord (1991), da muzejskega obiskovalca spodbuja k plemenitenju obstoječega vedenja na njemu najprimernejši način (učni slog), mu omogoča kritično (samo)refleksijo, spoznanje (izkustvo) in ponotranjenje vsebine (identiteta). Konstruiranje znanja poteka skozi proces osmišljevanja lastnih izkušenj in vrednot (Hooper-Greenhill, 2000: 138-140). Z vključevanjem obiskovalcev $\mathrm{v}$ interpretacijo muzejskih predmetov védenje, poprej »obča resnica«, »zdrava pamet« ali »dejstvo«, zdaj postane spremenljivo, negotovo. Iznenada se zavemo, da znanje ni enoznačno; sooblikujejo ga kustos in obiskovalci - v muzeju!

Proces tolmačenja in razumevanja muzejskih predmetov se tedaj spremeni, kajti mnenj,

S programom Mediator v kulturi smo v slovenskih muzejih želeli doseči boljše, poglobljeno poznavanje silno neheterogene, kulturno in izkustveno nadvse raznolike skupine starejših odraslih. Da se to ni zgodilo že prej, najverjetneje lahko pripišemo številnim slabšalnim stereotipom, ki označujejo starejše tudi v postmoderni družbi, pa tudi pomanjkanju znanja o generacijskih značilnostih. Najmočnejše obeležje posameznih generacij namreč ni njihova starost in tako najmočnejše obeležje starejših odraslih prav tako ni starost, marveč vse kaj drugega. Njihov človeški in kulturni kapital, denimo, sta dovolj pomembnejši obeležji, ki ju v muzeju velja še posebno upoštevati. 
razmišljanj, doživljanja in odgovorov obiskovalcev muzejski kustos ne more predvideti. V ospredje prihajajo osebne zgodbe in zgodbe skupnosti, ponotranjene resnice o kulturi in dediščini, ki jih nemalokrat mlajši muzejski kustos, denimo v primeru starejših obiskovalcev, težko razume. Če je občutljiv opazovalec, se od obiskovalcev hitro uči in dojame lahko, da ti nosijo v sebi vedenje in svoje doživljanje vrednega, svoje doživljanje kulturne dediščine, ki ju je treba šele odkriti. Še več, muzejski kustos tedaj odkrije, da imajo starejši obiskovalci izkustveno znanje, da so nosilci nesnovne kulturne dediščine, ki bi jo veljalo vključiti v muzejsko okolje, ji dati prostor, da se razmahne, da preživi in zaživi. O tem smo razmišljali ob uvajanju starejših prostovoljnih kulturnih mediatorjev v slovenske muzeje.

»Razumevanje sedanjosti in preteklosti, način, kako muzejske predmete tolmačimo, postaneta odvisna od življenjskih zgodb posameznikov ter od socio-kulturnih značilnosti neke skupnosti« (Sandell, 2002: 15). Nov, post(moderni) muzejski koncept $\mathrm{v}$ ospredje postavlja nesnovno kulturno dediščino (v najširšem pomenu besede) in varovanje dediščine po načelu kontinuitete kulturnih vrednot. $\mathrm{Ni}$ več poglavitno, poudarja Hooper-Greenhill (2000: 152), da muzej zbirko povečuje - evidentiranje in zbiranje gradiva je stara paradigma - pomembneje je, kaj in na kakšen način muzej z zbirko, ki jo ima, sporoča. Razstavi,

Muzeji ne zrcalijo več le okusa družbene elite in ne temeljijo več le na znanstvenem preučevanju muzejskih predmetov. Svoje delovanje širijo na vso družbo, najboljše med njimi pa zaposlujejo tudi družbena in politična vprašanja današnjega časa (Rasse, 1999). V starajoči se družbi so starejši odrasli, njihov prispevek k vrednemu življenju skupnosti in generacij, njihovo učenje pomembno družbeno vprašanje, ki ga muzeji ne morejo zaobiti. klasičnemu modelu enosmerne komunikacije, se pridružujejo nove muzejske dejavnosti pred in po razstavi, ki so usmerjene $\mathrm{v}$ družbo. To so lahko nove oblike družbene organiziranosti in nove skupnosti; umeščanje učnih izdelkov obiskovalcev v muzejski razstavni program; obdobja, ko muzej uporabljajo različne lokalne skupnosti, muzejski prostovoljci vseh starosti, v muzeju za daljši čas gostujoči umetniki, znanstveniki, pisatelji ipd. Muzejska dejavnost naj seže izven muzejskih sten, se dotika življenj posameznikov in skupnosti, ustvarja in bogati človeški in socialni kapital ter prispeva k večji družbeni trdnosti (Sandell, 2007; Newman, 2005).

\section{KONCEPCIJA IN IMPLEMENTACIJA MODELA MEDIATOR V KULTURI}

Začetki izobraževanja starejših kulturnih mediatorjev segajo v leto 2006, ko je bilo med Slovensko univerzo za tretje življenjsko obdobje in Narodnim muzejem Slovenije vzpostavljeno prvo programsko sodelovanje na področju ohranjanja kulturne dediščine v obliki organiziranega prostovoljnega dela. ${ }^{1}$ Prvi slušatelji - prostovoljni kulturni mediatorji so se pod mentorstvom zgodovinarke, muzejske svetnice dr. Maje Žvanut s svojim delovanjem vključili v razstavo Slovenski jezik: identiteta in simbol. Kratka zgodovina Slovencev. Osnovna vloga starejših kulturnih mediatorjev je bila (in še vedno je) individualnim obiskovalcem približati vsebinski koncept razstave, katere posebnost je v velikem številu muzejskih predmetov in obsežnosti stenskih pojasnil $\mathrm{v}$ razmeroma majhnem razstavnem prostoru, posvečenem pregledu slovenske zgodovine. Kulturni mediator nadzira razstavni prostor, in ko vanj vstopi obiskovalec, ga prijazno sprejme ter mu ponudi informacije o razstavi. Predstavi postavitev razstave in predvideni potek ogleda, posamezne vsebinske sklope ali celotno razstavo na željo obiskovalca tudi 
V modelu Mediator v kulturi smo povezali izkustveno znanje starejših $\mathrm{z}$ nesnovno obliko kulturne dediščine in model zasnovali kot presečišče dveh konceptov: dejavne starosti in varovanja kulturne dediščine po načelu izvornosti in kulturne kontinuitete. Zdi se, da sta se v imenovanem modelu srečno prekrižali dve težnji h kontinuiteti: kultura posameznih generacij starejših odraslih, njihova želja in njihova prizadevanja po osebnostni rasti in darovanju znanja, ter kulturna dediščina, katere temeljna značilnost sta kontinuiteta vrednosti in vrednega ter plemenitenje posameznika in skupnosti.

obrazloži, postreže mu s tiskanim gradivom in ga, če je potrebno, usmeri $\mathrm{k}$ dodatnim virom informacij. Zgodbe muzejskih predmetov, ki $\mathrm{v}$ prostoru tvorijo vsebinsko zaokroženo celoto, kulturni mediator pozna bodisi iz izobraževanja, ki $\mathrm{v}$ ta namen poteka na univerzi in v muzeju, bodisi - in to je pomenljivo! - iz zakladnice lastnih življenjskih izkušenj in znanja. Izhodišče komunikacijskega procesa, ki se zgodi v muzejskem prostoru, ostaja razstava, nosilcev informacij pa je več in sežejo onstran štirih muzejskih sten: muzej (predmet), obiskovalec in kulturni mediator. Vloga kulturnega mediatorja je predvsem $v$ tem, da vzajemnost različnih spoznanj, razmišljanj, pogledov (na isto temo) vzpodbudi (Gellereau, 2005).

Izbira besedne zveze »mediator v kulturi« ni naključna - porodila se je iz različnih, v družbo usmerjenih pogledov. $S$ poimenovanjem »mediator v kulturi« smo želeli preseči podobo osamljenega, onemoglega in neukega starejšega človeka in prispevati k uveljavljanju novega pogleda na starost in staranje. Želeli smo tudi preseči avtoritarni vzorec znanstvenega tolmačenja kulturne dediščine in $\mathrm{v}$ ta proces vključiti starejše generacije kot nosilke kulture. Ali, kot je dejala prva mentorica prostovoljnih kulturnih mediatorjev v Narodnem muzeju Slovenije: »Kulturni mediator v muzeju naj spozna bistvo muzejskega dela, da bo lahko postal razširjevalec informacij in (spo)znanj o slovenski premični kulturni dediščini in s tem tudi o pomembnem delu naše preteklosti ter o vlogi muzejev kot varuhov materialnega zgodovinskega spomina.« (Žvanut, 2008: 77). Kulturni mediator to počne $\mathrm{v}$ javni vlogi, ki jo prevzema v muzeju, pa tudi (in predvsem) znotraj svojih socialnih mrež (družina, lokalna skupnost, skupnost kolegov slušateljev na univerzi), skupnostnih povezav torej, ki jih človek naniza skozi življenje. V skupni dejavnosti smo tudi želeli povezati različne generacije. In ne nazadnje, ker je delovanje kulturnega mediatorja prostovoljno, smo z novo obliko muzejske dejavnosti želeli prispevati $\mathrm{k}$ spreminjanju konvencionalnih prepričanj o prostovoljnem delu kot amaterski in prostočasni dejavnosti, za katero velja zmotno prepričanje, da temelji zgolj na dobroti (do drugega) in se zanjo ni treba dosti in poglobljeno izobraževati. Na vprašanja, kakšno je družbeno poslanstvo prostovoljstva starejših na najrazličnejših področjih skupnega bivanja - tudi kulture, kako razviti vsebinske in organizacijske možnosti za prostovoljsko dejavnost v muzeju, kako prostovoljce in zaposlene $\mathrm{v}$ muzeju izobraževati in usposabljati za trajno skupno delovanje, je univerza za tretje življenjsko obdobje zlahka dala odgovore, saj je, tako kot druge nevladne organizacije, zrasla na prostovoljnem delu in je zgovoren dokaz, da nasledki prostovoljnega dela izboljšujejo življenje ljudi in skupnosti (Findeisen, 1998).

Prve prostovoljne kulturne mediatorje smo pridobivali iz vrst članov študijskih krožkov zgodovine, arheologije, umetnostne zgodovine in sorodnih humanističnih ved, študijskih skupin torej, ki se tematsko povezujejo z dejavnostjo muzeja. Za kandidate smo na univerzi organizirali uvodno srečanje, ki je bilo namenjeno predstavitvi vsebinskih in organizacijskih vidikov prostovoljnega dela $v$ muzeju, spoznavanju poklicnih poti slušateljev univerze in njihovih morebitnih izkušenj z organiziranim prostovoljstvom (zunaj družinske skupnosti), 
še posebno so nas zanimali njihovi motivi za delo v muzeju. Polovica kandidatov je že imela izkušnje s prostovoljnim delom, predvsem na področju socialnega varstva in izobraževanja, nihče pa še ni delal kot prostovoljec v muzeju. Ko smo jih povprašali po motivih za delo $\mathrm{v}$ muzeju, jih je glavnina navedla željo po spoznavanju novih vsebin, en kandidat je poudaril željo po navezovanju stikov z ljudmi. Skoraj pri vseh se je pokazalo, da poklicno s kulturno dediščino niso bili povezani.

Sledilo je skupno izobraževanje $\mathrm{v}$ prostorih muzeja, namenjeno tako kulturnim mediatorjem, ki se vključujejo v muzej, kot tudi zaposlenim v muzeju, ki v svoje delovno okolje sprejemajo nove (prostovoljske) sodelavce. Poudarek celostnega izobraževanja zato ni bil samo na strokovni (muzejski) vsebini, ampak tudi na družbenem poslanstvu prostovoljstva starejših ter etiki prostovoljnega dela.

Izobraževalnemu seminarju so sledila skupinska srečanja $\mathrm{z}$ mentorico $\mathrm{v}$ muzeju. Usposabljanje je bilo sprva namenjeno predvsem spoznavanju muzejskih razstav. Mentorica je kulturnim mediatorjem delila strokovno gradivo in jih usmerjala $\mathrm{k}$ iskanju virov in literature. Da bi prostovoljce kar najbolje seznanila s posameznimi segmenti muzejske razstave, pa tudi z metodami in oblikami dela z obiskovalci, je k sodelovanju vabila muzejske kolege, poznavalce različnih področij. Eno od srečanj je bilo posvečeno spoznavanju dobre prakse na področju prostovoljske dejavnosti v muzejih, s čimer je univerza želela prispevati $\mathrm{k}$ opolnomočenju cele skupine - kulturnih mediatorjev in mentorice - za uspešno prostovoljstvo. Razgovor, vodeni ogledi razstave, oblikovanje vprašanj, samostojni študij literature, medsebojno poročanje, simulacija prostovoljnega dela - to so glavne metode izobraževanja in usposabljanja kulturnih mediatorjev. Učenje poteka v manjši skupini, v katerih so poleg mentorja tudi slušatelji sami s svojimi izkušnjami, znanjem in kulturo vir učenja skupine.

Kulturni mediatorji se v vlogi tolmačev kulture in varuhov kulturne dediščine vključu- jejo v najrazličnejše muzejske dejavnosti. Nosijo vidno priponko s svojim imenom in priimkom, nazivom prostovoljec oziroma prostovoljka in logotipom kulturni mediator. Ta ima veliko vrednost, saj pomaga graditi identiteto prostovoljca in pripadnost javni muzejski ustanovi. Delo kulturnih mediatorjev je simbolično nagrajeno.

\section{ŠIRJENJE MODELA - S STALNIMI NOSILCI DO TRAJNE IZOBRAŽEVALNE OBLIKE IN TRAJNIH PRAKS}

Nov model vzajemnega učenja in organiziranega prostovoljstva starejših $\mathrm{v}$ muzejskih ustanovah smo s povezovanjem nosilcev lokalnega razvoja - univerz za tretje življenjsko obdobje in muzejev - prenesli $\mathrm{v}$ druge slovenske kraje. Izobraževalne seminarje za muzejske delavce in prostovoljce smo vsebinsko obogatili z osebnimi pričevanji kulturnih mediatorjev, dodali smo tematiko o družbeni odgovornosti muzejev. Kulturni mediatorji so se uspešno vključili v najrazličnejše oblike muzejskega dela, njihovo delovanje je odmevalo tudi v širši javnosti. ${ }^{2}$ Vzpostavili smo mrežo koordinatorjev, ki v posameznih ustanovah organizirajo delo kulturnih mediatorjev, skrbijo za urnike in pogodbe, koordinirajo usposabljanje prostovoljcev $\mathrm{z}$ mentorji (muzejskimi kustosi), spremljajo odzive vseh vpletenih, sodelujejo s predstavniki univerz za tretje življenjsko obdobje pri pridobivanju novih prostovoljskih sodelavcev in promociji dejavnosti. Razvejana mreža kulturnih mediatorjev, mentorjev in koordinatorjev starejših prostovoljcev se občasno združi v dogodkih, ki jih Univerza za tretje življenjsko obdobje organizira posebej za njih.

Razvojni model Mediator v kulturi smo vključili v slovensko raziskovalno nalogo o vplivih izobraževanja na dejavno staranje (Knežević, 2008) in $\mathrm{v}$ hrvaško raziskovalno nalogo o prostovoljski dejavnosti v muzejih (Papić, 2008), kot primer 
dobre prakse je bil predstavljen v nemškem Glasilu mreže za dejavno državljanstvo v muzejih (NETBEM 2008) in je zajet v najnovejše nacionalno poročilo Andragoškega centra Slovenije o celostnem modelu izobraževanja starejših odraslih (Bogataj in Findeisen, 2008).

\section{ZAKLJUČEK}

Starajoča se družba potrebuje vizijo svojega razvoja na različnih področjih družbenega življenja in tako tudi v kulturi. Tako se v starajoči se družbi zlagoma spreminjajo koncepti, teorije, nastajajo nove politike $\mathrm{v}$ podporo dejavnemu staranju. Oblika dejavnega staranja je izobraževanje in je prostovoljno delo starejših.

Muzej izgublja svojo nekdanjo vlogo varuha in posrednika elitne kulture. $\mathrm{V}$ prihodnje bodo muzeji odkrivali nove oblike kulturne vzgoje, nove oblike za posredovanje in soustvarjanje kulturne dediščine skupaj z onimi, ki jih muzej kot obiskovalce skuša pritegniti. Ker se družba stara, se bodo muzeji posebej obračali k starejšim odraslim, zato je dobro, da jih začnejo poglobljeno spoznavati in vključevati v svoj muzejski svet, ne le kot obiskovalce, marveč tudi kot sooblikovalce tega sveta. To je pomembna priložnost tudi za muzejske ustanove in njihovo osebje, kajti ustvarjanje novih, času primernejših prostovoljskih vlog za starejše pomembno spreminja tudi muzej in muzejske delavce. Starejši so nosilci bogate nesnovne kulturne dediščine. Naša skupna naloga je, da ta zaživi v stiku z muzejskimi delavci in muzejskimi obiskovalci. Ker so starejši nosilci nesnovne kulturne dediščine, je prav in je vredno organizirati in spodbujati njihovo prostovoljno delo v muzejih.

$\mathrm{Z}$ razvojem modela Mediator v kulturi so postale $\mathrm{z}$ izobraževanjem pridobljene kompetence starejših slušateljev Slovenske univerze za tretje življenjsko obdobje vidne, potrjeno koristne široki javnosti. Zato smo vse dejavnosti pospremili z obsežno kampanjo za prepričevanje javnosti. Sleherno izobraževanje skupin z družbenega obrobja je namreč tudi izobraževanje za pridobivanje moči. Spreminja naj posameznike pa tudi okolje in zlagoma naj privede do vsaj rahlih družbenih sprememb. $Z$ nenehnim izobraževanjem starejših in odpiranjem vrat muzejev starejšim prostovoljcem dosežemo dvojno destigmatizacijo v prostoru: omilimo stigmo starosti, stigmo učenja in izobraževanja starejših odraslih in stigmo prostovoljnega dela. Povezovanje muzejskih ustanov z organizacijami civilne družbe in njenimi ciljnimi skupinami ob tem postaja del poslanstva muzejev in kaže pot do obiskovalcev, tudi onih iz družbeno obrobnih skupin.

\section{LITERATURA IN VIRI}

Bogataj, N., Findeisen, D. (2008). Celostni model izobraževanja starejših odraslih v Sloveniji: upoštevajoč družbene temelje in vlogo izobraževanja odraslih, značilnosti starejših odraslih in primere dobre prakse. Ljubljana: Andragoški center Slovenije.

Bračun, R. (2007). »Učenje in izobraževanje za dejavno državljanstvo: prostovoljni kulturni mediatorji v Narodnem muzeju Slovenije «. V: Knez, D. (ur.). Zborovanje Slovenskega muzejskega društva. Slovenj Gradec, 4.-6. oktobra 2007. Ljubljana: Slovensko muzejsko društvo.

Bračun, R. (2007). Prostovoljni kulturni mediatorji v Narodnem muzeju Slovenije. Ljubljana: Slovenska univerza za tretje življenjsko obdobje.

Bračun, R. (2008). »Izobraževanje za organizirano prostovoljno delo«. V: Krevl, I. (ur.). 7. Festival za tretje življenjsko obdobje: zbornik. Ljubljana: Inštitut Hevreka.

Chambord, E. (1991). »Les themes de la contextualisation chez les visiteurs de musée «. Revue canadienne de l'éducation. 16, 3, 292-312.

Findeisen, D. (1998). Prostovoljstvo starejših za starej$\check{s}$ e. Ljubljana: Univerza za tretje življenjsko obdobje.

Findeisen, D. (2009). »Starejši prostovoljni kulturni mediatorji: konceptualni temelji prostovoljstva starejših in razvoj modela sodelovanja med Slovensko univerzo za tretje življenjsko obdobje in muzeji«. V: Knez, D. (ur.). Zborovanje Slovenskega muzejskega društva. Bovec, 1.-3. oktobra 2009. Ljubljana: Slovensko muzejsko društvo.

Gellereau, M. (2005). Les mises en scene de la visite guidée. Communication et médiation. Pariz in $\mathrm{Bu}-$ dimpešta: L' Harmattan.

Hooper-Greenhill, E. (ur.) (1994). The Educational Role of the Museum. London in New York: Routledge. 
Hooper-Greenhill, E. (2000). Museums and the Interpretation of Visual Culture. Abingdon in New York: Routledge.

ICOM (2005). Icomov kodeks muzejske etike. Ljubljana: Društvo ICOM.

Klercq, J., Zwart, J. (ur.) (2007). Lifelong Learning as a Key to Active Citizenship. Baarn.

Knežević, S. (2008). Izobraževanje starejših na Univerzi za tretje življenjsko obdobje za osebnostno rast in sodelovanje $v$ družbi. Diplomsko delo (tipkopis). Ljubljana: Filozofska fakulteta.

NETBEM (2008). »Voluntary Cultural Mediators for Slovenian Museums. Netzwerk Bürgerschaftliches Engagement im Museum (NETBEM)«. Newsletter. Dostop: http://www.ooemuseumsverbund.at; 11. junija 2009.

Newman, A. (2005). Understanding the social impact of museums, galleries and heritage through the concept of capital, Heritage, Museums and Galleries. Abingdon in New York: Routledge.

Papić, V. (2008). Volonteri u muzejima: današnje stanje $i$ potrebe muzeja. Diplomsko delo (tipkopis). Zagreb: Filozofska fakulteta.

Rasse, R. (1999). Les musées a la lumiere de l'espace public: Histoire, évolution, enjeux. Pariz: L' Harmattan.

Sandell, R. (2002). Museums and the combating of social inequality; roles, responsibilities, resistance, Museums, Society, Inequality. Abingdon in New York: Routledge.

Sandell, R. (2007). Museums, predjudice and the reframing of diference. Abingdon in New York: Routledge.

Tavčar L. (1997). »Narodna galerija nagrajuje zveste obiskovalce «. Argo. 40, 2, 67-69.

Tavčar, L. (2003). Zgodovinska konstitucija modernega muzeja kot sestavine sodobne zahodne civilizacije. Ljubljana: ISH in Narodna galerija.

Tavčar, L. (2009). Homo spectator. Uvod v muzejsko pedagogiko. Ljubljana: Pedagoški inštitut.

Žvanut, M. (2008). »Kulturni mediatorji v muzejih zelo potrebna novost«. V: Krevl, I. (ur.), 7. Festival za tretje življenjsko obdobje: zbornik. Ljubljana: Inštitut Hevreka.

1 Razvojni model Mediator v kulturi sodi v sklop tako imenovanih tematskih izobraževalnih programov za organizirano prostovoljstvo starejših v javnih ustanovah, ki ga je Slovenska univerza za tretje življenjsko obdobje razvila pod vplivom dela v evropskem projektu LACE (Lifelong learning and Active Citizenship in Europe's ageing society, slov. Vseživljenjsko izobraževanje in dejavno državljanstvo starejših Evropejcev) v obdobju od 2005 do 2007. Prvi fazi, konceptualni zasnovi in implementaciji programa v Narodnem muzeju Slovenije (2006-2007), je sledil prenos modela v Arhitekturni muzej Ljubljana (2007), Muzeje Radovljiške občine (2008) in Loški muzej Škofja Loka (2008), vselej povezujoč muzej in univerzo za tretje življenjsko obdobje $v$ posameznem kraju (tudi v obliki pisnega dogovora o sodelovanju). Ob finančni podpori Islandije, Lichtensteina in Norveške prek Finančnega mehanizma EGP in Norveškega finančnega mehanizma (projekt Starejši - nosilci in posredniki nesnovne kulturne dediščine; 2008-2009) je univerza v sodelovanju s Slovenskim muzejskim društvom in Slovenskim etnološkim društvom program razširila v Dolenjski muzej Novo mesto, Slovenski etnografski muzej, Tehniški muzej Slovenije in Prirodoslovni muzej Slovenije. $V$ dveh letih se je $v$ osem slovenskih muzejev prek programa Mediator $v$ kulturi vključilo skupno 63 posameznikov (6 moških in 57 žensk), starejših od 55 let. Če temu dodamo še Mestno knjižnico Ljubljana (Knjižnico Otona Župančiča), s katero je univerza vzpostavila podobno programsko sodelovanje leta 2008, število kulturnih mediatorjev naraste čez 70 ljudi. Prevladujejo ženske.

2 Predstavljamo nekatere najpomembnejše prostovoljske vloge, ki jih opravljajo starejši kulturni mediatorji v muzejih. V Narodnem muzeju Slovenije kulturni mediatorji sprejemajo obiskovalce na stalnih in občasnih muzejskih razstavah, v Muzejih Radovljiške občine sodelujejo pri muzejskih delavnicah za otroke in drugih pedagoških dejavnostih, podobno tudi v Prirodoslovnem muzeju Slovenije. V Tehniškem muzeju v Bistri se vključujejo predvsem $v$ delo dokumentacijske narave (muzejska knjižnica). V Dolenjskem muzeju Novo mesto sodelujejo v oddelku za arheologijo in $v$ oddelku za umetnostno zgodovino, kjer pomagajo pri pripravi muzejskih razstav (omeniti velja razstavo del Božidarja Jakca v letu 2009, saj so mnoge podatke o slikarju in njegovih delih prispevali prav starejši kulturni mediatorji). V Arhitekturnem muzeju Ljubljana so kulturni mediatorji angažirani predvsem pri popisovanju dediščine slovenskih modernih arhitektov, kar muzej občasno tudi javno predstavi v okviru tako imenovanih muzejskih večerov. Slovenski etnografski muzej je starejše kulturne mediatorje vključil v najrazličnejše oblike varovanja in predstavljanja etnološke dediščne. Skupina kulturnih mediatorjev v Škofji Loki skrbi za Škoparjevo hišo, muzej na prostem, in občasne razstave na Loškem gradu. Za izjemne učne uspehe in bogatitev lastnega znanja je leta 2008 prejela nagrado Andragoškega centra Slovenije. 